Monika Wakula

Siedlce University of Natural Sciences and Humanities in Siedlce

Faculty of Economic and Legal Sciences

\title{
SIZE DIVERSITY SHAPING FINANCIAL CONDITION OF RURAL COMMUNES OF SIEDLCE SUBREGION
}

\section{Zróżnicowanie zmiennych ksztaltujących kondycję finansową gmin wiejskich podregionu siedleckiego.}

Kondycja finansowa podstawowych jednostek samorzadu terytorialnego jest zjawiskiem złożonym. Przez wielu autorów utożsamiana jest ona z sytuacja finansowa danej gminy. Znajomość czynników wplywajacych na niq ułatwia organom zarzqdzajacym jednostkami samorzqdu terytorialnego podejmowanie właściwych decyzji finansowych. Celem artykutu jest próba oceny zróżnicowania czynników ksztattujących stan finansów gmin podregionu siedleckiego w latach 2014-2016. Niezbędne dane zostały zaczerpnięte z Banku Danych Lokalnych. Do opisu ksztaltowania sie poziomu poszczególnych zmiennych $w$ podregionie siedleckim wykorzystano miary tendencji centralnej, miary rozproszenia i koncentracji. W wyniku przeprowadzonych badań stwierdzono, że gminy z badanego terenu sq najbardziej zróżnicowanie pod względem dochodów własnych. Natomiast najbardziej jednorodną grupę stanowią pod względem cyklu rotacji środków budżetowych.

Słowa kluczowe: kondycja finansowa, gmina, podregion siedlecki, zróżnicowanie

\section{Introduction}

Units of local government play a significant role in fulfilling the needs of local and regional communities. Decision-making processes taking place within financial economy of basic units of territorial selfgovernment have significant consequences concerning social and economic development, and finally they influence the quality of life of local communities. While making financial decisions, particular analytic tools as well as numerous financial instruments should be applied.

Being aware of the present and future financial situation is essential while making decisions concerning finance. Financial condition is a phenomenon influenced by many variables. Despite multifaceted character of the phenomenon, knowledge on the real financial condition of particular units of territorial government is undoubtedly essential. It allows local authorities to compare the situation in the unit with the one of neighboring units of the local government. The knowledge also provides those in power with important information while making financial decisions.

\section{Financial condition of communes}

As a result of political changes which took place in Poland after 1989, communes were transformed from a subject following top-down directives into an economic subject allowing for market demand and looking for an answer to the question: how to act to provide satisfaction to local communities while fulfilling their needs and how to be competitive and ensure commune development at the same time? To choose the appropriate way of conduct, units of territorial government have to make a number of 
decisions. Some of the decisions concern only the process of accumulation, allocation and management of public funds. They are called financial decisions and are made by the authorities of units of the local government and by employees entitled to it within short and long-term periods (Filipiak, 2009). The decisions are a part of the management process. It results from the fact that they execute the manager's right to decide and co-decide about strategic directions and key objectives of a given unit of a local government. It allows us to state that financial decisions are a part of a financial management, understood as a part of the process of total management which deals with regulating and looking for sources of financing both current and investment activities. The effect of the decisions may influence the financial condition of a particular unit. In total, financial situation can be understood as a condition, form, location and efficiency of a given unit.

L. Bednarski and T. Waśniewski (1996) identifiy financial condition with the concept of financial situation. Its evaluation aims at identification mainly those areas which are managed in an improper way and may endanger the activity of the unit. The basic source of information necessary for the evaluation are financial reports and significant external information. An important instrument aiming at evaluating financial situation is ratio analysis, which is a part of a financial analysis.

A similar opinion is expressed by M. Sierpińska (1997). She claims that financial condition and financial situation are identical notions and lie within the area of interest of financial analysis. The analysis comprises an initial and developed analysis of financial reporting, sources of revenue and directions of expenditure, the analysis of the financial result. Evaluation of financial situation is mainly based on the analysis of financial liquidity, indebtedness and efficiency of the activity. It is the main tool for making all decisions.

Financial condition is a kind of a barometer of developmental possibilities of units expected by the authorities of the units.

J.Hozer, W. Tarczyński (1997) also claim that the notions of financial condition and financial situation are equivalent. They state that ratios used in financial analysis serve to describe the financial condition of an organization and the scope of the analysis will enable us to identify strengths and weaknesses of an economic entity as well as its opportunities and risks. It includes the evaluation of financial liquidity, management of assets and assessment of indebtedness.

The definitions of financial conditions presented above lead to the conclusion that it is most common to identify it with the financial situation of a particular unit. The assessment of the financial situation is carried out in key areas of its activity (liquidity, acting efficiency and indebtedness) with the use of a set of financial ratios. Account taken of the above, a financial condition of a unit of a local government can be defined as a condition of its finance which is the result of the authorities' activities aiming at generating enough financial means to settle its accounts in a particular period of time. The obtained financial position should enable local authorities to provide such a level of services to satisfy the inhabitants (Groves, 1984). In a wider scope, financial condition of a unit of local government may refer to a longer period of time and concern the possibility to cover all the expenditure arising in every budget year and the one that occurs only in a particular budget year or a few years ( f.e. connected with some investments). 
The definition of a financial condition applied in the article allows us to formulate a conclusion that it can be treated as a result of a broadly defined finance management (making financial decisions connected with looking for capital and investment decisions) as well as a determinant of managerial processes (Czekaj, Dresler, 2008). Therefore, it can be stated that there is a feedback loop between a financial situation and financial management. Finance is, thus, the reflection of all economic events taking place in the units (Bednarski, 2007).

As it was mentioned above, finance management in units of local government is a decision-making process which requires comprehensive information. Its relevance decides on its efficiency and economy of activities as well as on the level of execution of tasks set to local units. Preparation and making decisions in the conditions of huge changes occurring in the environment with a dynamic development of technology, globalization of economic processes and requirements for initiating cross-border and international cooperation require constant access to full, current and reliable information. It is necessary for making both strategic decisions concerning future functioning and development of units of local government and current decisions which focus on performing on-going tasks of the units (Dylewski, 2009).

Analytical information, especially the one of financial and accounting character, is particularly crucial. It enables people responsible for making decisions at various levels of management of the sector of the public finance to analyse changes occurring in the market, their reasons and the objectives pursued, measures taken and factors confounding the process and task execution.

Essential information on financial situation of a unit of local government is provided by financial analysis. To achieve high quality reliable information as far as finance management is concerned, it is necessary to choose the appropriate research method. In case of financial analysis, the method consists of typical and repetitive ways of collecting, preparation, analysis and interpretation of empirical data used to achieve justified answers to factual questions (Dylewski, Filipiak, Gorzałczyńska-Koczkodaj, 2006).

A particular type of the methods applied in the financial analysis is the one based on financial indicators, which reflect the relation of two measures.

Ratio analysis is one of the most popular methods of measurement and evaluation of financial condition (Siemińska, 2003) It supplements analyses of basic financial documents and is based on the study of mutual relations between particular elements of financial reports.

Applying the method is advisable due to the following reasons (Pomykalska, Pomykalski, 2007):

- it enables standardization of analysis, which is significant mainly for banks because while applying for a loan, a local unit should present the same picture of the situation in various branches of a bank and obtain the same reply concerning credit credibility

- $\quad$ it gives an opportunity of comparison with average ratios for a given group of self-governing units

- it makes it possible to observe trends and progress within a few years 
Ratio analysis of units of local government is used to evaluate its financial liquidity and credit credibility, allows us to identify possibilities of rationalization of the budget economy and indicate consequences of financial execution of various scenarios development.

Ratio analysis aims at determining strengths and weaknesses of finance of units of territorial government. The ability to generate revenue, directions in expenditure, financial result and possibility of taking a load are subject to it.

Ratio analysis deals with the following area covering distinct tasks:

- the analysis of financial balance

- the analysis of the turnover of budgetary funds

- the analysis of financial liquidity

- the analysis of indebtedness.

The goal of the analysis of financial balance is to identify the level of financial independence of the budget and the ability to pay long-term debt. The level of financial independence of a commune can be evaluated on the basis of budget expenditure coverage by non-refundable own income outside the scope of subsidising and subventions originating elsewhere than in a loan, as well as repayable revenue in the long term (Wakuła, 2005).

A ratio of financial independence indicates to what extent own income of the budget covers its expenditure. The rest of the expenses must be covered by subsidies, subventions, loans and other external sources. The increase of the value of the ratio demonstrates a higher level of financing budgetary expenditure by own income. The longer own income covers budgetary spendings, the higher financial autonomy is.

The task of the ratios of the turnover of budget resources is to inform about the past of the turnover of resources, which is available in the budget as well as about the pace of turnover of particular elements of the resources of the significant meaning to maintain budgetary balance.

Budgetary balance is understood as an equality between budget income and expenditure. It is such a condition of the commune finance which enables timely fulfillment of current liabilities without using external means, not covered in the accepted budget.

The evaluation of the level of financial liquidity of the budget is also significant while analyzing financial situation of units of local government. The notion of financial liquidity in the subject literature is widely discussed. Due to that fact, definitions differ and depend on the point of view concerning the issue. Most frequently, financial liquidity is understood as:

- the ability to cover timely payment of current liabilities which are due to be covered within a year

- the ability to provide an adequate amount of means to finance current expenses

- availability of liquid assets in such amount that they can be easily cashed in when needed, and the means can be used to regulate due or predictable payments.

Thus, it can be stated that financial liquidity is the ability of a given entity to attain financial flow enabling the regulation of required liabilities and covering unexpected spendings (Wędzki, 2002). 


\section{Data and methods}

The aim of the article is to evaluate diversity of basic categories shaping financial condition in rural communes of Siedlce subregion. The study was conducted on 31 basic units of local government. Data used to evaluate financial situation was taken from the Local Data Bank and concerned the period between 2014 and 2016. Taking into account substantial, formal and statistical criteria, a group of variables was selected which were used to describe financial condition of the studied communes. The research was carried out taking into consideration the following measures: total income, income per capita, own income, own income per capita, subventions, subsidies, total expenditure, expenditure per capita, assets-related spending and current spending. Among indicators of financial analysis, taking into account data availability, the following indicators were used: indicators of financial autonomy, subvention rate, subsidy rate, indicator of the turnover of budget resources, budget surplus ratio and debt ratio.

To evaluate the level of shaping the variables listed and their diversity the following criteria:

- measure of central tendency ( arithmetic mean and median)

- measure of dispersion (standard deviation and variation)

- measure of concentration (Kurtosis)

\section{Results}

On the basis of data from Table 1, it can be stated that financial economy of the analysed communes was conducted in the conditions of a constant increase of income, which in 2016 amounted to $28,39 \%$. It was mainly caused by the growth in subsidy $(107 \%)$. Such a high increase of the subsidy was influenced by the introduction of child-support benefit resulting from the Act Of 11 February 2016 on State Aid In Child Rearing (the Family 500+ programme) and the increased number of applications concerning family benefits, higher number of events containing natural disaster elements resulting in the necessity to pay designated benefits for people who were victims of the events.

Table 1. Level, dynamics and structure of budgetary income of rural communes of Siedlce subregion between 2014 and 2016

\begin{tabular}{lccccccccc}
\hline Description & \multicolumn{2}{l}{ Level [in mIn] } & \multicolumn{5}{l}{$\begin{array}{l}\text { Dynamics } \\
\mathbf{2 0 1 4 = 1 0 0}[\%]\end{array}$} \\
& $\mathbf{2 0 1 4}$ & $\mathbf{2 0 1 5}$ & $\mathbf{2 0 1 6}$ & $\mathbf{2 0 1 5}$ & $\mathbf{2 0 1 6}$ & $\mathbf{2 0 1 4}$ & $\mathbf{2 0 1 5}$ & $\mathbf{2 0 1 6}$ \\
\hline own income & 183,49 & 196,55 & 201,57 & 107,12 & 109,85 & 36,19 & 36,11 & 30,96 \\
subventions & 214,17 & 216,75 & 222,04 & 101,21 & 103,67 & 42,24 & 39,83 & 34,11 \\
subsidies & 109,39 & 130,94 & 227,39 & 119,70 & 207,87 & 21,57 & 24,06 & 34,93 \\
total income & 507,04 & 544,24 & 650,99 & 107,34 & 128,39 & 100 & 100 & 100,00 \\
\hline
\end{tabular}

Source: Own elaboration

In the structure of budgetary income, the most dominant group throughout the whole research period are subventions. Their share decreased in 2016 by $8,13 \%$. In all 
analysed communes, educational subsidy constituted the biggest part. What is worrying is the fact that the share of own income decreased in total income by $5,23 \%$. It is a very unfavourable phenomenon due to the fact that income from own economic basis allows basic units of local government to develop the process of forecasting the budget in an easier and more predictable way. It is also the income which is left to the disposal of the commune giving the feeling of financial security of the conducted activity.

Siedlce subregion is diverse with respect to size and structure of budgetary income. It is confirmed by the value of the coefficient of income inequality above $55 \%$. Average income in communes of the analysed subregion in 2014 amounted to $15,8 \mathrm{mln}$, and in 2016 - 20,34 million PLN. 50\% of the studied communes had revenue of 18,3 million PLN at most, whereas the income of the other half was at the level of at least 18,3 million PLN. The lowest value of income in total in 2016 was observed in Korczew commune $(10,25 \mathrm{mln}$ PLN), whereas the highest level of total sources of supply was noted in the commune of Siedlce $(67,54 \mathrm{mln}$ PLN). The coefficient of kurtosis amounted to 8,88 in 2016 and was higher than 3 , which means higher concentration around mean income achieved by communes of Siedlce subregion than in a normal distribution.

Financial potential of communes may be achieved by the comparison of budgetary revenue per capita. In 2016 , a mean income per capita in the studied communes amounted to 3879 PLN and was higher than the income in 2014 by 861,35 PLN. $50 \%$ of the analysed communes generated income per capita at the level of 3832,96 PLN at most. In this respect, the community of Siedlce subregion is homogeneous. The coefficient of variation for the variable was $9 \%$. The lowest income per capita was observed in Sterdyń commune (3233,10 PLN), whereas the higher income was noted in the commune of Ceranów.

As it was mentioned above, own income is significant for proper functioning of basic units of local government. In the studied period of time, income from own economic base amounted to 6,30 mln PLN. Siedlce subregion is characterized by high diversity in this respect. The coefficient of variation was $82 \%$. The commune with the lowest own income was Domanice. The highest level of own income was observed in Siedlce commune.

While analysing the diversity of income per capita (Table 2), it can be stated that the studied community in homogeneous with regard to own income per capita ( coefficient of variation was 35\% throughout all the analysed years). Basic units of local government in the analysed subregion in 2016 generated mean income per capita at the level of 1129,38 PLN. The lowest income was observed in Domanice commune, whereas the highest in the commune of Siedlce. Half of the basic units of local government achieved income per capita from own economic base at the level of at least 1096,14 PLN. 
Table 2. Basic statistical characteristics of own income per capita

\begin{tabular}{l|rrr}
\hline Description & \multicolumn{3}{c}{ Years } \\
& \multicolumn{1}{c}{2014} & \multicolumn{1}{c}{2015} & \multicolumn{1}{c}{2016} \\
\hline Arithmetic mean & $1050,33 \mathrm{zł}$ & $1131,84 \mathrm{zł}$ & $1129,38 \mathrm{zł}$ \\
Median & $1014,43 \mathrm{zł}$ & $1065,41 \mathrm{zł}$ & $1096,14 \mathrm{zł}$ \\
Maximal value & $1464,84 \mathrm{zł}$ & $1731,18 \mathrm{zł}$ & $1798,52 \mathrm{zł}$ \\
Minimal value & $686,83 \mathrm{zł}$ & $752,73 \mathrm{zł}$ & $760,65 \mathrm{zł}$ \\
Standard deviation & $223,48 \mathrm{zł}$ & $256,10 \mathrm{zł}$ & $243,26 \mathrm{zł}$ \\
Coefficient of variation & $19,56 \%$ & $22,63 \%$ & $21,54 \%$ \\
Coefficient of kurtosis & $-0,83$ & $-0,53$ & 1,80 \\
\hline
\end{tabular}

Source: Own elaboration on the basis of data from the Local Data Bank between 2014 and 2016.

In 2016, 11 communes generated own income above the mean. Most of them was from the poviat of Sokołów.

The direction and level of budgetary expenditure influence the financial situation of local governments. Analysed communes in 2016 met expenditure of 622,86 mln PLN and it was higher than in 2014 by $107,99 \mathrm{mln}$ PLN. The level of the budget category increased more slowly than the level of income. The comparison of income and budgetary expenditure showed that the level of spending was higher than revenue in 2014. In 2015 and 2016 the situation was reverse. The income exceeded budgetary expenditure by $15,76 \mathrm{mln}$ PLN and $28,13 \mathrm{mln}$ PLN, respectively. It is a very positive situation. The communes have enough means to cover their spendings. With respect to budgetary expenditure, the studied community is diverse ( the coefficient of variation was $52 \%$ ). The lowest level of expenditure was observed in the commune of Korczew, whereas the highest - in Siedlce commune.

Among basic groups of expenditure ( current and assets-related spending), current spending was characterized by the highest dynamics. Its level in 2016 increased by $28,96 \%$. In the analysed year, assets-related spending decreased by $20,10 \%$, which is a negative phenomenon. It may be seen as an inhibition of investment processes in basic units of local government of the analysed subregion. It is confirmed by the decrease of the share of this type of spending in total expenditure by $6,51 \%$. The structure of expenditure of communes is dominated by current spending whose share increased by $5,52 \%$. In all the studied years, more than a half of current expenditure of communes was intended for the payment of salaries.

Financial situation of the studied units indicates the level of expenditure per capita, as well. The value of the coefficient of variation at $10,50 \%$ confirms a low dispersion and the mean value characterises the level of expenditure of the analysed units in an accurate way. Average spending per capita in communes of Siedlce subregion was 3721,81 PLN in 2016 and was higher than in 2014 by 669,30 PLN. 50\% of the studied communes had expenditure per capita at 3693,15 PLN at least. On the basis of the data included in Table 3, it can be noticed that there is a decreasing tendency of the indicators 
of financial autonomy. In 2014, the studied communes could finance 128 budgetary day relying on their own income, whereas in 2016, it was possible to finance only 116 days. It can be considered to be a negative phenomenon. On the basis of the coefficient of variation (16\%), it can be concluded that the studied community is homogeneous in this respect. Half of the communes of Siedlce subregion achieved the indicator of financial autonomy at the level of $29,53 \%$ at most, which translates into 106 days.

Table 3. The level of indicators of ratio analysis in communes of Siedlce subregion between 2014 and 2016.

\begin{tabular}{|c|c|c|c|c|c|c|}
\hline \multirow[t]{3}{*}{ Description } & \multicolumn{6}{|c|}{ Level } \\
\hline & \multicolumn{2}{|c|}{2014} & \multicolumn{2}{|c|}{2015} & \multicolumn{2}{|c|}{2016} \\
\hline & $\%$ & dni & $\%$ & dni & $\%$ & dni \\
\hline Indicator of financial autonomy & 35,63 & 128 & 37,41 & 133 & 32,36 & 116 \\
\hline Subvention rate & 40,90 & 147 & 40,59 & 146 & 32,67 & 117 \\
\hline Subsidy rate & 21,25 & 76 & 24,78 & 89 & 36,50 & 131 \\
\hline $\begin{array}{l}\text { Cycle of the turnover of budget } \\
\text { resources }\end{array}$ & - & 354 & - & 370 & - & 376 \\
\hline Budget surplus ratio & - & -5 & - & 10 & - & 16 \\
\hline
\end{tabular}

Source: Own elaboration on the basis of the Local Data Bank from 2014 to 2016.

Empirical values of the subvention rate indicate that in 2016 communes of Siedlce subregion used subvention to cover $32,67 \%$ of their spendings. It was less than in 2013 by $8,23 \%$. The commune of Domanice financed its expenditure from the general transfer through the longest period of time. It was 173 budgetary days. The shortest period, only 82 days, concerned the commune of Siedlce.

The analysis of the subsidy rate allows us to state that the studied basic units of local government covered 131 days with subsidies in 2016. It was 55 days more than in 2014. It was the result of the Family 500+ programme mentioned above. On the basis of the analysis of the cycle of the turnover of budget resources, a positive phenomenon of the lengthening of the cycle can be noticed. In 2016, communes managed to finance their expenditure from their available funds throughout the whole year and attain a budget surplus at 28,13 mln PLN. Rzepki commune financed its expenditure the longest.

While analysing the budget surplus ratio, a significant improvement can be observed. In 2016, it was possible to use budgetary surplus to finance 16 days of the next budgetary year. In the studied community in the last analysed year, there were 6 communes with budget deficit. Their number decreased in comparison to 2014 by 12 .

While analyzing the level of the total debt ratio, it can be stated that its average level in 2016 amounted to $18,2 \%$ and was lower than in 2014 by $8,7 \%$. Half of the analysed local governments had no more than $47,6 \%$ of debt. The studied group is diverse in this respect. The highest level of the total debt ratio was observed in the commune of Stock (47,6\%). Indebtedness of the commune is the result of undertaking a number of investments and the necessity to take loans for this purpose. It is confirmed 
by the increase of investment expenditure in 2016 by $23 \%$. The studied community contains two units which throughout the whole analysed period of time did not show any liabilities. These are the communes of Suchożebry and Stara Kornica.

The consequence of using repayable sources is the increase of the costs of the service. In the last of the analysed years, the communes exceeded 3,7\% of their income to cover debt service.

\section{Summary}

The conducted analysis of spatial differentiation of communes of Siedlce subregion with regard to variables shaping financial situation makes it possible to present observations and draw conclusions:

Among all the factors influencing financial condition of rural communes of Siedlce subregion, the biggest differences were observed with regard to own income.

The division of communes into groups of units of similar level of own income per capita indicated that the communes with the highest level of income included the biggest number of communes of the poviat of Sokołów. The group with the lowest own income per capita was dominated by communes of the poviat of Siedlce. The lowest diversity was observed in communes with regard to the turnover of budget resources.

The decrease in the share of own income in the total revenue is a worrying phenomenon. It leads to the decrease of the feeling of security concerning conducted activities.

\section{Literatura}

B. Filipiak (red.).(2008), Ekonomiczne i organizacyjne instrumenty wspierania rozwoju lokalnego i regionalnego, Zeszyty Naukowe Uniwersytetu Szczecińskiego nr 530, Szczecin.

Bednarski L. (2007), Analiza finansowa w przedsiębiorstwie, PWN, Warszawa.

Bednarski L., Waśniewski T. (1996), Analiza finansowa w zarządzaniu przedsiębiorstwem, Fundacja Rozwoju Rachunkowości w Polsce, Warszawa 1996.

Czekaj J., Dresler Z. (2008), Zarządzanie finansami przedsiębiorstw. Podstawy teorii, PWN, Warszawa.

Dylewski M. (2009), Kierunki i kryteria wykorzystania metod oceny sytuacji finansowej jednostek samorządu terytorialnego w warunkach kryzysu.

Dylewski M., Filipiak B., Gorzałczyńska - Koczkodaj M. (2006), Finanse samorządowe, Narzędzia, decyzje, procesy. PWE, Warszawa.

Filipiak B. (2009), Metodyka kompleksowej oceny gospodarki finansowej jednostki samorządu terytorialnego, Difin, Warszawa.

Groves S.M. (1984), An introduction to Evaluating Financial Condition, [w:] J. Matzer Practical Financial Management. New Techniques for local Government, ICMA, Practical Management Series, Washington.

Hozer J., Tarczyński W., Gazińska M., Wawrzyniak K., Batóg J. (1997), Metody ilościowe w analizie finansowej przedsiębiorstwa, Seria statystyka w praktyce, Zeszyt 2, GUS, Warszawa 1997.

Nowak S. (1985), Metodologia badań społecznych, PWN, Warszawa.

Pomykalska B., Pomykalski P. (2007), Analiza finansowa przedsiębiorstw, PWE, Warszawa 2007, Siemińska E. (2003), Finansowa kondycja firmy, metody pomiaru i oceny, Poltext, Warszawa 2003.

Sierpińska M., Wędzki D. (1997), Zarządzanie płynnością finansową w przedsiębiorstwie, PWN, Warszawa. 
Wakuła (2005), Samodzielność finansowa gminy, Samorząd Terytorialny 2005 nr 5, KiK, Warszawa.

Wędzki D. (2002), Strategie płynności finansowej przedsiębiorstwa, Oficyna Ekonomiczna, Kraków.

Financial condition of basic units of territorial government is a complex phenomenon. Some authors associate it with the financial situation of the particular commune. Knowledge of the conditions influencing the situation enables governing bodies of the territorial government to make proper financial decisions. The aim of the article is an attempt to evaluate the diversity of factors shaping financial condition of communes of Siedlce subregion between 2014 and 2016. Essential data was taken from the Local Data Bank. The following features were taken into account while shaping the level of particular variables in Siedlce subregion: the measure of central tendency as well as the measures of dispersion and concentration. The conducted research indicated that communes in the studied region were the most diverse as far as their own revenue was concerned. However, they were the most homogenous when it came to the cycle of rotation of budgetary appropriations.

Key words: financial condition, commune, Siedlce subregion, diversity.

Informacja o autorze:

dr Monika Wakula

Wydział Nauk Ekonomicznych i Prawnych

Uniwersytet Przyrodniczo-Humanistyczny w Siedlcach, Katedra Ekonomii

e-mail: monika.wakula@uph.edu.pl

ORCID: 0000-000-1-9896-7997 